\title{
REVIEW OF TAXATION REGULATORY DOCUMENTS ISSUED IN THE PERIOD OF NOVEMBER-DECEMBER 2013
}

\author{
L.Anisimova
}

During the period under review, November-December 2013, fiscal policy guidelines were formulated in the President's Address to the Federal Assembly on 12.12.2013 and his speech at the $9^{\text {th }}$ Annual Press Conference on 19.12.2013. In particular, new tax schemes and allowances were announced. In our opinion, change of task priorities and reorientation of federal financial entities to support a sustainable revenue base of the state is vital amid stagnation. Develop a free market, ensure efficient performance of market players is critical in pursuing the foregoing aims. Financial regulation of the economy goes beyond taxes. The greatest challenge is counteract economic monopolies.

In his Annual Presidential Address to the Federal Assembly and at the press conference President Putin described many proposals aimed at enhancing the economic development in the Russian Federation.

The country's top leaders consider it necessary to resume the election of local government authorities at the municipal level, i.e., mayoral elections. The currently unbalanced revenue base and budget liabilities at this level will require measures aimed at supporting local budgets: elaborate general principles of organization of local self-governance, build-up of a strong, independent, solvent power at the local level.

Local budgets are supposed to be strengthened through making changes to the current patent system so that legal entities and self-employed entrepreneurs hire foreign labor force on the patent basis. The price of a patent will be determined at a constituent territory of the Russian Federation. Buying a patent for a certain period will allow a foreign worker to legitimize his/her terms of employment while payment for the patent strengthen the local budget revenue base and prevent uncontrolled migration, because each patent will be issued for a certain territory.

Measures of financial support to the regions were announced. Regional costs on creating the infrastructure of industrial and technology parks, business incubators are supposed to be compensated to a constituent territory of the Russian Federation through intergovernmental transfers. Additional federal taxes levied within three years from the enterprises located at such territories will be the source of such transfers.

Preferential tax treatment allowed for new production facilities located in the Far Eastern District and Transbaikalia (except production of hydrocarbons) is planned to be extended to the accelerated development zones located in Eastern Siberia, the Krasnoyarsk Territory and the Republic of Khakassia: a 5-year holiday for profit tax, mineral extraction tax (except crude oil and natural gas), land tax, profit tax, a as well as reduced insurance premium rate.

In addition, President Putin confirmed that governors are entitled to grant a 2-year tax holiday for new small enterprises (businesses) engaged in the production, social, and research areas, but the decision on the introduction of such allowances will lay within the scope of competence of governors (such a scheme was adopted to compensate for short-received regional budget revenues with the federal budget resources).

A special emphasis was paid to prevent further capital outflow through offshore zones. According to the presented data, offshore zones account for $20 \%$ of the Russia's exports ( $\$ 111 \mathrm{bn}$ ) and $50 \%$ of the Russia's investment. The issue is so vital that the Russian Government is ready to revise its agreements on avoidance of double taxation with the countries which grant a preferential tax treatment, if tax authorities of such countries fail to send to the Russian Federation the information of beneficiaries' revenues from Russia. Russian organizations whose beneficiaries are hidden in offshore zones are not supposed to either be allowed to participate in public contract tenders, or receive public guarantees.

A single federal portal of control measures with a special ID assigned to each inspection is expected to be created with a view to protecting business and reducing corruption pressure. Information disclosure on the portal will allow the initiator of an inspection, the inspected entity, the motives of the inspecting body to be identified, and the results of the inspection to be seen.

In our opinion, priority financial objectives of the contemporary economic development in the Russian Federation should also include counteracting monopolies which exist in one guise or another and artificially redistribute financial resources for their own benefit, destroying a free market. Given a critical importance of the task to develop a free domestic market in the 
Russian Federation in order to overcome economic stagnation, the objectives of federal financial bodies should be adjusted, in our opinion.

Let's explain our point of view. Monopolization is a natural way of market development. The mechanism of monopolization is well described in the economic (classical) literature. Monopolization is intended to get rid of competitors and establish monopoly prices (beginning with predatory price dumping and ending with monopolistically high prices when other manufacturers are gone) which later reaches the ceiling, thereby redistributing public resources for the benefit of the monopolist. Therefore, the monopoly price contains a monopoly markup over monopolist costs which is a variation of compulsory payments due by consumers to the owners of the monopoly. Problems begin when the monopoly needs powers of authority to forcibly retain its monopoly status in the market. The monopoly tends to 'coalesce' with the state at different levels for the purpose of using the available state administration body for its own benefit. Such a coalition is dangerous, because state power authorities blink the fact that the resources, which should go to the budget in a free market, turn out to be available for the monopoly.

If the Russian Federation wants to be more attractive to investors, it should first of all focus on the objectives of control and development of the market through indirect methods, without strong-arm interference. A free market itself can detect and reject monopoly when the latter just begins to destroy free competition. It is at this stage when the state can most efficiently counteract monopoly, but this requires constant monitoring over the market conditions. However, the federal ministries and agencies can hardly yet recognize free market promotion as their key objective to enhance the federal revenue base, instead they replace this objective with the current task of looking for resources to service ever growing federal expenditures.

Following is an example. Substandard financial base in the regions and local self-governments has long turned out to be a serious issue for the federal budget. Regional debts will unavoidably result in growth in the Russia's sovereign debt which has been growing over the past few years ${ }^{1}$. Furthermore, the core fede-

1 «Госдолг России превысит доходы бюджета через десять лет», сайт lenta.ru от 6.12.2013 ["Russia's sovereign debt to exceed budget revenues in nine years", lenta.ru dd. 06.12.2013]. «Минфин предупредил, что к 2025 году госдолг превысит доходы бюджета на 6,2 процента, а к 2030 году - на 22,7 процента. Рост госдолга чиновники объяснили сокращением поступлений от приватизации после 2018 года. Таким образом, заимствования станут единственным источником финансирования дефицита, но за их счет может быть покрыт дефицит в размере не более 1,11,2 процента ВВП» [“The Ministry of Finance has warned that Rus- ral government authorities don't get to the bottom of the regional issues and deficit in the regional revenue base, because there are not commissioned to do such a task. The Ministry of Finance of Russia would rather suggest to replace the governor of a region with budget deficit than engage core ministries and arrange for a systemic analysis of the causes of failures in the regional revenue base ${ }^{2}$. The following chain lines up: federal budget issues will unavoidably keep aggravating with degradation of the regional revenue base which depends largely on small and medium-sized businesses, but the federal government authorities prefer formal decisions (по праву 'Russia's vertical power structure') to analysis of the reasons of weak activity of small and medium-sized businesses. According to the available information, it is regional and municipal monopolies that constitute a key obstacle against the development of the regional and local business. The following happens, more or less. Certain firms or entrepreneurs purchase by themselves or through straw parties commercial real estate in a region and offer for rent to regular entrepreneurs, but either with large floor spaces so that the lessee subsequently look for a sub-lessee (the buy-or-pay principle), or the lessee allows an entrepreneur to work without an agreement, i.e., the latter has to run a shadow business, pays a monopoly price to the lessor who in turn pays the real property tax only. The lessee becomes lessor's hostage, because he actually would run an illegal business. A large-scale inspection is impossible, because of mismatch of the data available at the Tax Service and the Federal Service for State Registration, Cadastre and Cartography (Rosreestr). The regional level is "too small" for the Federal Anti-Monopoly Service. As a result, the Tax Service monitors - exclusively via documents $^{3}$ - property tax revenues while the regional budget base remains without revenues. In this case, it would be better to announce a tax amnesty for

sia's sovereign debt will exceed $6.2 \%$ budget revenues by 2025 and $22.7 \%$ by 2030 . Public servants explained that the sovereign debt will grow in response to reduction in revenues from privatization after 2018. Borrowings will therefore become the sole source of deficit financing. However, borrowings can cover a deficit of not more than 1.1-1.2\% of GDP"].

«Минфин оценил нехватку средств в бюджете в 10 триллионов рублей», сайт lenta.ru от 5.12.2013 ["The Ministry of Finance estimates a $\mathrm{Rb} 10$ trillion deficit in the budget", lenta.ru dd. 05.12.2013]. «В результате государственный долг вырастет примерно на половину, с нынешних 12 до более 18 процентов ВВП» [“As a result, Russia's sovereign debt will increase to account for almost $50 \%$ of the current $12 \%$ to more than $18 \%$ of GDP"].

2 Regional financial problems can hardly be reduced to a federal center's simple statement of the fact of drastic increase of their tax burden.

3 Regretfully, while the Tax Service and the Rosreestr have electronic databases, both of them have not been verified over the last 15 years. 
lessees and forcibly put the non-profit-making commercial real estate to a public leasehold competition on common basis at market prices. In our opinion, the introduction of numerous tax regimes would provide no adequate control of the situation, because they are applied discretely and introduced according to formal criteria. It is, therefore, important to expand the usage of a universal criterion of potential income appraisal of commercial real estate in the form of imputed tax per unit area of non-residential premises - it should be done to stimulate lessors to legally lease out such floor spaces for commercial use.

In our opinion, analysis of the causes of problems faced in starting and running small and medium-sized businesses in specific regions (including anonymous surveys) should be entered the list of top priority lines of the federal executive authorities.

Regarding tax incentives for the economic development, it implies in a general tax burden relief. However, unfortunately, it is the policy of pin-point tax allowances that prevails in the Russian Federation. The lack of any well-defined position towards non-expediency of introduction of tax allowances often leads to strategically incorrect decisions. For instance, we repeatedly warned on the impermissibility of granting tax allowances to organizations which are engaged in speculative trading (operations without economically feasible sources of income) exposed to high risks, including those secured by borrowings from third parties. It refers to state support of dealers (not brokers) in speculative trading in the financial market (they are entitled to use profits before taxation, i.e., budget resources, to build up provisions for impairment of securities), application of an exclusively preferential (which was previously applied to banks only) procedure for charging losses and even short-received speculative interest building up the profit of microfinance organizations, etc, to the account of the budget. The situation in western countries differs. In the United States, banks may not use their capital to purchase securities ${ }^{1}$. Spe-

1 Е.Мериминская «Волкер» поправит банки «Правило Волкера» - революция в банковской системе США, сайт gazeta.ru от 11.12.2013. «В банковской системе США революция: регуляторы приняли «правило Волкера», которое запрещает банкам зарабатывать на спекуляциях. ...Правило запрещает банкам торговлю ценными бумагами за счет собственных средств, то есть торговые операции для собственной прибыли...Деятельность банков на бирже теперь может проходить только в интересах клиентов, или в качестве market-maker, когда банк принимает риски хранения и торговли бумагами определенного эмитента, или для минимизации рисков (хеджирование). ...Правило названо в честь Пола Волкера - главы Федрезерва в 1979-1987 годах. Волкер назвал повышенную активность банков на фондовом рынке одной из причин кризиса 2008 года и предложил законодательно culations are considered dangerous for the financial market, because they encourage players towards risk transactions (the higher is the risk, the higher is the profit), the higher is the demand for risk assets (so is their speculative price), the higher are the risks. In the end, a financial crisis turns out to be more destructive, because playing risks resembles a pyramid scheme, resulting in a little number of high-profit gainers and a great number of those who pay high risks with their hard-earned money. In our case, the state at its own account provides extra hedging (by granting exclusive tax allowances) for professional speculators' risks.

Indeed, anti-evasion measures in the Russian Federation are facing problems and slow rate of introduction of most efficient counteraction methods into practice. A good illustration of this is the Letter dd. October 31, 2013, No. CA-4-9/19592 of the Ministry of Finance of Russia and the Federal Tax Service of Russia.

The foregoing Letter was prepared with a view to improving the quality of control measures and contains a review of the practice of consideration of taxpayers' complaints and tax-related disputes on unjustified tax benefit at arbitration courts. The review covers a set of arbitration cases in which the Supreme Commercial Court of the Russian Federation took the part of tax authorities. The Federal Tax Service of Russia provides detail description of each lawsuit, the essence of tax violation, and the documented evidence of the tax violation presented in the course of legal proceedings. Therefore, the review contains a list of the violations which tax authorities should focus on in their day-to-day operation, as well as a standard method of evidence collection and documentation for each specific case so that tax authorities can make a standard evidence base which allows to win a lawsuit concerning similar tax violations.

The review pays a special attention towards the method of collection of evidence showing that taxpayers' business transactions formally meet the requirements of the applicable tax laws and regulations, but

ограничить ее. «Правило Волкера» стало ключевым пунктом финансовой реформы Додда - Фрэнка» [E. Meriminskaya “"Volcker" will repair banks. The "Volcker Rule" is a revolution in the U.S. banking system", gazeta.ru от 11.12.2013. "A revolution in the U.S. banking system: Regulators have adopted the "Volcker Rule" which bans speculation-based earnings for banks. ...Under the rule, banks may not trade in securities with their own equity, i.e., trade for their own profit ...From now on banks may operate in the stock exchange for the benefit of their customers, or as market-makers, when a bank assumes risks of safekeeping and trade in securities of a specific issuer, or for mitigation of risks (hedging). ... The rule was named after Paul Volcker, the Head of the FRS in the period of 1979 thru 1987. Volcker explained that banks' hyperactivity in the stock market was a cause of the crisis in 2008 and suggested that such an activity should be legally restricted. The "Volcker Rule" became the key point of the Dodd-Frank financial reform"]. 
have no reasonable business goal other than unjustified preferential tax terms. This is a most challenging tasks, because tax authorities have to dispute the contents of contractual relations. Tax authorities are found themselves engaged in a hard, low-performance paperwork, because agreements (contracts) differ and there is no way to find a standard approach in such a situation. Such a paperwork is very costly and requires top-class professionals.

It seems to be time to rely on financial efficiency of tax administration in selecting methods of control, controlling a gain in budget revenues against $\mathrm{Rb} 1,0$ of extra labor (wage) costs at the Federal Tax Service of Russia and its territorial branches. Engagement of a big number of tax authorities in numerous legal proceedings to struggle "for each pretty penny" might actually result in unreasonable increase in administration costs and create illusive struggling for budget revenues.

In our opinion, tax authorities should focus primarily on channels of tax-free transfers under cross-border transactions and a consistent work on the elimination of tax allowances in the applicable laws and regulations. It is these methods of tax evasion that may cause heaviest losses for the budget. Our position needs explanation. It is hard to hide turnovers for the purpose of indirect taxation (VAT and excises) in case of minimized tax allowances, because VAT is based on the conflict of interests between the suppliers and the buyer: sorted and decrypted information on transactions and turnover volumes automatically goes to tax authorities. Hidden profit in the production sector will unavoidably become evident in individuals' consumption and may be taxed within individuals' personal income. A method of matching personal income with expenses is used for the provision of evidence. This is a standard practice for tax authorities at many countries, because large expenses are documented. In the Russian Federation, however, this mechanism has not been widely used and introduced for public servants only.

Cross-border transactions constitute the key channels of VAT and excise evasion while income tax exemption (tax allowances) constitutes the key channels of income tax evasion (льготы). For instance, in case of profit tax allowance, such profit has already acquired the status of corporate equity. If, for instance, a large hydrocarbon company purchases (at a high price) products from any enterprises which are entitled to profit tax allowance, the price of the products and (allowable) profit of such enterprises begin to grow instantly. However, the higher is the price, the higher are the costs and the lower the (taxable) profit of the hydrocarbon company. As soon as transactions are closed, profit (withdrawn from taxation) may either re- turn to the hydrocarbon company as investment or interest-bearing loan, or may be used for distribution of dividends at reduced rates, or may be simply credited to accounts and shared in other countries (outside the Russia's jurisdiction). There are many such enterprises entitled to tax allowances can be established. One may understand why the Russian Government wants to facilitate business development in the country, but it only can be resolved by reducing a general level of tax burden, not through tax allowances. Unlikewise, tax allowances will preserve outdated production facilities, artificially overstating their profitability, or can be used to transfer income without taxation to other jurisdictions (not necessarily offshore ones).

Following are the documents which were adopted in the period of November thru December 2013 and are worth mentioning.

1. The Russian Government Regulation of 30.11.2013, No. 1101 established the maximum value ( $\mathrm{Rb} 624,000)$ of the assessment base for insurance premiums at public extrabudgetary funds (the Pension Fund of Russia, the Social Insurance Fund, the Federal Compulsory Medical Insurance Fund), which is to take effect on 01.01.2014. In addition, the Federal Law of 02.12.2013 No. 333-FZ retained the current level of tariff rates (total $-30 \%$, including the Pension Fund of Russia - 22\%, the Social Insurance Fund $-2.9 \%$, the Federal Compulsory Medical Insurance Fund $5.1 \%)$. Contributions above the maximum threshold ( $\mathrm{Rb} 624,000$ ) established by the Russian Government Regulation are to be paid at a $10 \%$ rate to the Pension Fund of Russia only.

Preferential treatment will remain in force until 2018 for organizations and entrepreneurs entitled to simplified tax system for the types of economic activity listed in Clause 8, Part 1, Article 58 of the Federal Law of 24.07.2009 No. 212-FZ (hereinafter referred to as the Federal Law No. 212-FZ); for pharmacy organizations entitled to single tax on imputed earnings, which are covered by Clause 10, Part 1, Article 58 of the Federal Law No. 212-FZ; for non-profit organizations engaged in the provision of social services, $R \& D$, culture and popular sports (Clause 11 Part 1 Article 58 of the Federal Law 212-FZ), which are covered by the simplified taxation system, and some other organizations covered by Clause 14, Part 1, Article 58 of the Federal Law 212-FZ. Such organizations are to pay contributions at a reduced rate of $20 \%$ to the Pension Fund of Russia only.

2. The Federal Law of 02.12.2013 No. 323-FZ established that tariffs of premiums of compulsory social insurance against work injuries and occupational diseases will remain unchanged $(0.2 \%)$ in 2014 and the planning period of 2015 and 2016. 
3. The Federal Law of 02.12.2013 No. 336-FZ established that the minimum wage will increase to Rb 5554 monthly from January 1, 2014. The minimum wage is used to determine a taxable base for the assessment of insurance premiums at public extrabudgetary funds by self-employed entrepreneurs, lawyers, notaries, and other persons engaged in private practice according to Article 14 of the Federal Law No. 212FZ.

4. The Board of the Eurasian Economic Commission's Decision of December 2, 2013, No. 279 provided significant explanations to the rules of application of the method designed to determine a customs commodity cost on the basis of the cost of transaction with imported goods, which refer to the method of recognition of costs embedded into the customs commodity cost. This method is intended to prevent improper overstatement of customs commodity cost in order to artificially distribute sales proceedings among foreign trade participants. The arrangement about qualification of costs under foreign trade transactions at the international level into those which are to be embedded into the customs cost (direct) and those which are to be allocated to overall performance of a counterparty (indirect) is very important for equitable distribution of the revenue base among the budgets of different states.

Article 5 of the Agreement of 25.01.2008 "On the Determination of the Customs Cost of Commodities Moved Through the Customs Border of the Customs Union" establishes the costs embedded into the cost of commodities, in particular, they refer to a contract for international carriage, license agreement, etc.

Buyer's personal costs (save for the costs provided for by Article 5 thereof are not deemed to be indirect and embedded into the customs cost of imported goods), if such costs have no effect on the price of goods established by the seller. For instance, if the buyer conducts at his own account an independent examination of the goods to be purchased, the costs of such examination (testing) may not be a term of the purchase and sale contract, the examination may not change the condition of the goods to be purchased and therefore is not to be deemed to be a part of the equipment manufacturing process. Therefore, the costs of such examination may not be embedded into the customs cost of goods and are fully covered by the buyer.

5. The Federal Law of 2.12.2013 No. 345-FZ made amendments to Article 855 of the Civil Code of Russia. The priority of debit transfers if there are insufficient resources to satisfy claims of all creditors was harmonized with the Ruling of the Constitutional Court of the Russian Federation dd. 23.12.1997, No. 21-P. Tax authorities' orders to write off and transfer arrears on taxes and levies to the budgets of the budget system of the Russian Federation, as well as orders issued by authorities which control payment of insurance premiums to write off and transfer insurance premiums to the budget of public extrabudgetary funds are classified as third priority along with payment documents providing for transfer or disbursement of funds to pay labor remuneration to persons employed under a labor contract (agreement). Writs of execution on other monetary claims are classified as fourth priority.

6. The Order of the Ministry of Economic Development of Russia dd. 07.11.2013, No. 652 "On the Establishment of Deflator Coefficients (DCs) for 2014" was officially published in November 2013, a little bit later than it was expected. Deflator coefficients are used for the adjustment of tax bases for certain types of taxes (personal income tax, simplified tax system, single tax on imputed earnings, and patent tax system (PTS).

The Order of the Ministry of Economic Development approved the following values of deflator coefficients for 2014:

- The deflator coefficient required for calculation of fixed advanced payments on personal income tax payable by foreign nationals employed by individuals in the Russian Federation on a patient basis, $-1,216$;

- The deflator coefficient required for calculation of an upper threshold of organization's earnings with a view to switching to the simplified tax system, - 1,067;

- The deflator coefficient required for calculation of a tax base for the single tax on imputed earnings, - 1,672;

- The deflator coefficient required for calculation of a lower and upper value of potential annual earnings of the self-employed entrepreneur for the purpose of assessment of the tax payable if the patent tax system is applied -1,067.

The Letter of the Ministry of Finance of Russia and the Federal Tax Service of Russia of December 4, 2013, No. GD-4-3/21750 explained that lower and upper values of earnings of self-employed entrepreneurs entitled to the patent tax system which are established by the laws and regulations of the constituent entities of the Russian Federation may not be less than the lower and upper value which is determined on the basis of the DC established for 2014 by the Ministry of Economic Development (the lower value is not less than $\mathrm{Rb} 106,7$ thousand while the upper value is $\mathrm{Rb} 1067,0$ thousand).

According to the estimates made by ConsultantPlus experts, monthly advance payment of personal income tax for a patent purchased by a foreign individual 
employed by Russian individuals on the basis of the DC established for 2014 in the Regulation of the Ministry of Economic Development $(1,216)$ will be $\mathrm{Rb} 1216$.

For the purpose of application of the simplified tax system $(1,067)$, the deflator coefficient adjusts the upper threshold of earnings over nine months of the current year, thus allowing the simplified tax system to be applied in the year to come, and the upper threshold of current year earnings above which the taxpayer loses such entitlement. The foregoing limits are $\mathrm{Rb} 48,015 \mathrm{~m}$ and $\mathrm{Rb} 64,02 \mathrm{~m}$ respectively given the adopted DC.

The tax base of the single tax on imputed earnings is calculated by multiplying the basic revenue per type of activity established in the Tax Code of the Russian Federation by the adjusting factor (K2) established by regional government authorities and the deflator coefficient (K1) determined by the Ministry of Economic Development. The DC1, which was established in 2014 , is 1,672 .

7. The Federal Law dd. 25.11.2013 No. 317-FZ (with regard to healthcare) made amendments into the Tax Code of Russia.

Under a new version, VAT exemption covers not only physicians in private practice, but also self-employed entrepreneurs engaged in medical activities (i.e., those engaged in the provision of medical services) on a constant basis (perhaps, paramedics, nurses, etc.). Specified were operations of VAT-exempted state unitary enterprises - an explicit list of services of organizations providing drug dependency treatment, residential social service institutions for persons with mental disorders, etc. was included.

Amendments concerning the procedure for granting tax exemption or applying a reduced $(10 \%)$ VAT rate upon sales of medical products were adopted. Since the Federal Law introduced a new universal definition - "drugs intended for medical use and medical products", - let's dwell on the potential problems that might occur here.

The laws and regulations in force: the Russian Government Regulation of 15.09.2008, No. 688 approved a Medical Products Code List as consistent with the All-Russian Product Classifier (OK 005-93), which are subject to a $10 \%$ VAT rate upon sale thereof, as well as a Medical Products Code List as consistent with the Foreign Economic Activity Commodity Classification of Russia (RF FEACC), which are subject to a $10 \%$ tax rate on imports to the customs territory of Russia; the Russian Government Regulation of January 17, 2002, No. 19 approved a List of Vital, Essential and Necessary Medical Equipment exempted from VAT on the territory of the Russian Federation pursuant to Articles 149 and 150 of the Tax Code of Russia.
Thus, a disputable situation may arise from January 1, 2014 when VAT exemption is granted, because the common term "medical products" will be used instead of "medical equipment" and "medical goods". To avoid any problems, one should be governed by the position of the Ministry of Finance of Russia which considers a registration certificate of a product with the code specified in the aforementioned lists approved by the Russian Government Regulations as the key condition for granting tax exemption or a $10 \%$ preferential tax rate. The case is that Part 4, Article 38 of the Federal Law of 21.11.2011, No. 323-FZ "On the Healthcare Principles in the Russian Federation" prohibits distribution on the territory of the Russian Federation of medical products other than those which are duly registered according to the procedure established by the Government of Russia. The conflict of terminology is settled by holding a registration certificate and direct reference to the code of a given product in the lists approved by the Government of Russia.

The permanent registration certificate issued during registration of medical products (medical equipment) is valid until January 1,2017 . Such permanent certificates are subject to replacement with a new form of registration certificates upon the foregoing date.

Article 333.32.2 was introduced into the Tax Code of Russia, under which the value of a state duty payable for legally significant actions during state registration of medical products will be determined from December 25, 2013. In addition, allied types of state duties were provided for.

From January 1, 2014 tangible costs incurred for the assessment of the Single Agricultural Tax will include the cost of medicines for veterinary purposes only (amendments to Article 346.5 of the Tax Code of Russia).

8. The Letter of the Federal Tax Service of Russia of November 26, 2013, No. GD-4-3/21097 and the Letter of the Ministry of Finance of Russia of 07.11.2013 No. 03-01-13/01/47571 provided a procedure for establishing a single law enforcement practice in the Russian Federation. The point at issue is that in the case when explanatory letters of the Ministry of Finance of Russia and/or the Federal Tax Service of Russia fail to comply with the rulings issued by highest judicial agencies, such letters of the Ministry of Finance of Russia and/or the Federal Tax Service of Russia are deemed to be cancelled from the date of official publication of the rulings of such highest judicial agencies (including posting of such rulings and letters on official websites). In executing their powers, the Ministry of Finance of Russia and the Federal Tax Service of Russia are to be governed from the same date by the foregoing rulings and letters issued by highest judicial agencies. 